\title{
The Balkans after the 2004 Enlargement of NATO and the European Union: What Next?
}

\section{Mihail E. Ionescu*}

So much has been written in the past several years about the Balkans, yet some confusion still exists about what exactly constitutes the region. Therefore, at the outset of this essay, I will first make an attempt to geographically define the Balkans. There are more views - some of them very new - than just this one on the market regarding this issue. Of course, the classical concept still predominates: the Balkans comprises the countries of the Balkan Peninsula, which became part of the Ottoman Empire in the Middle Ages. In the twentieth century, the "Balkans" overlapped with "Southeastern Europe," and these two notions were used, and very often still are used today, to describe the same geographical area. Recently, some analysts have started referring to three geographical blocs, which today are quite distinct from the security point of view: the classical Balkans, the Black Sea area, and the Caspian area. They are considered to be parts of the northern tier of the most volatile region in the world, known as the "Greater Middle East," where the most dangerous threats to international security are thought to have their origin. Experts across the Euro-Atlantic community are now combining these three blocs into one larger area called "Greater South-East Europe." Recently, in July 2003, in Bucharest, the Institute for Political Studies of Defense and Military History, together with the National Defense University from Washington, hosted an international conference devoted to the topic "Southeast European Security after the 2004 Dual Enlargement." Among the invitees in attendance were experts not only from the classical Balkans, or South-Eastern Europe, but also from the former Soviet republics of Georgia, Armenia, and Azerbaijan, as well as from Ukraine and the Republic of Moldova.

Two points should be made here. First, the European Union considers that the classical Balkans are part of its own backyard, and after Romania and Bulgaria are admitted to the Union - hopefully in 2007-the EU will have the Black Sea and other new borders in the east and south-east. The EU is interested in extending stability to the full extent of its new borders - according to its documents, all the way to Moldova, the Caucasus, and the Black Sea. That means beyond the classical Balkans, the borders of Bulgaria and Romania. It seems that, at least in the conception of Brussels, the Balkans remain geographically what they were. On the contrary - and this is the second pointAmerican experts are more inclined to use the concept of Greater South-Eastern Europe, making the Balkans part of it alongside the Black Sea and the Caucasian areas.

\footnotetext{
* Brigadier-General Dr. Mihail Ionescu is at the Institute for Political Studies of Defense and Military History, Bucharest, Romania.

1 Ronald D. Asmus and Kenneth M. Pollack, "The New Transatlantic Project - A Response to Robert Kagan,” Policy Review (October-November 2002).
} 
In order to assess what will happen in the Balkans after the 2004 round of NATO and EU enlargement, I would present three scenarios. The basic assumption for the elaboration of the following three scenarios is the future of transatlantic relations. It seems to me that in the aftermath of the Iraq crisis, to ask questions about the solidity of the security connection between the United States and Europe is to display realism and a sense of responsibility.

The first scenario is based on the potential deepening of the transatlantic rift, which emerged during the Iraq crisis and the war itself. Doubting strongly that such an eventuality could become reality I raise it here as a theoretical possibility in order to assess its potential implications.

According to my opinion, if such a scenario were to gradually become reality, due to the competitive nature of relations between the two great Atlantic powers, the degree of cooperation between them would lessen as they develop diverging outlooks on international security. I cannot imagine the possibility of an actual clash between the two, so the cooperation will have to continue in different fields, but only on a small scale. NATO would be fatally compromised, and would perhaps disappear, and the European Union integration process would slow down dramatically, if it continued at all.

Whither the Balkans in this scenario?

First of all, it is highly probable that both the NATO and the EU enlargement processes will be stopped. This probability is based on the assumption that NATO will cease to function as a forum for reaching consensus between the two sides of the Atlantic, but will eventually become irrelevant due to the frequently opposing views expressed by different members ("old Europe" versus the U.S., "new Europe" versus "old Europe," etc.). ${ }^{2}$

This concern was expressed by Tony Blair, who declared in an interview given to the Financial Times in April 2003: "My fear is that if we don't deal with the world on the basis of a partnership between Europe and America, then we will in a sense put back in the world the divisions that we wanted to get rid of when the Cold War finished. [...] And I think that would be just a disaster for the world." Continuing in the same tone, Blair asserted in August 2003, also in an interview in the Financial Times, that "There is no more dangerous theory in international politics today than that we need to balance the power of America with other competitor powers, different poles around which nations gather. [...] Such a theory made sense in $19^{\text {th }}$ century Europe. Today, it is an anachronism to be discarded like traditional theories of security. What we need," he continued, "is not rivalry but partnership in the face of a common threat international terrorism."

Another assumption is that the EU integration process will weaken due to several factors, among which I would note the divisions among the great powers of Europe regarding the future of the EU and the pressure of the small and medium-sized members

${ }^{2}$ George Parker and Quentin Peel, "A Fractured Europe-Divisions Deepen Between Big and Small Countries, North and South, Elites and Their Electors," Financial Times, 17 September 2003. 
to gain an equal voice in an integrating continent. Leaving aside the fact that Turkey's candidacy for membership implies an extension of Europe towards Asia, rejecting it will raise the specter of more divisions inside NATO and Europe itself. On the other hand, to build the EU as a counterweight to the U.S. is unrealistic from many angles. It only needs mentioning that this would imply building a military capability of comparative strength, which for Europe would mean increasing military expenditures dramatically. This could not happen without affecting other budgetary allocations for a long period of time, primarily those connected with the welfare state, which would run against the overwhelming orientation of European public opinion (and the European electorate). Recently, the U.S. Ambassador to NATO, Nicholas Burns, said that ideas promoted in France to build up the EU as a counterweight to U.S. power in the world would be "a recipe for failure." 3

Second, arresting the NATO and EU enlargement processes would have a dramatic impact on the Balkans. Incentives for the countries in the area to promoting reform and enhance cooperation would disappear. More than that, the probability of intra- and inter-state tensions would increase, since the competition among the major actors on the world stage would feed domestic political friction and divergent foreign agendas in each country. Visiting Kosovo last year, General Richard Myers said that the United States will review its involvement in the Balkans, "with an option" on the table for a European force to take over. ${ }^{4}$ Currently, there are approximately 4000 American soldiers in the Balkans, of which 1500 are deployed in Bosnia and 2500 in Kosovo. Yet, in the context of divergences between the U.S and EU, the future of joint peace support operations (PSO) will be jeopardized. The Balkans will once again become what it had been several times in the last century's history: a hunting ground for the great powers.

Consequently, cooperation within the Balkan region will be a less attractive prospect. Different political forces inside each country will accommodate their own domestic and international agendas according to the temperature of the relations between the EU and the U.S. Nationalist political forces will take up more of the political space. Economic development will be problematic in the absence of EU and U.S. support. Internal and regional instability will increase, as well as the degree to which it is exported to neighboring areas.

One of the factors that would greatly diminish the probability of these negative developments in the classical Balkans is a rapid installment of U.S. military bases in some of the countries of the region. The U.S. has to capitalize on the present-day proAmerican orientation of the political elites and public opinion in the countries of the area. In such a way, the classical Balkans will be strongly connected to the Greater South-Eastern Europe region that is of so much interest to the U.S., and will develop bilateral relations with the U.S. instead of integrating into multilateral Euro-Atlantic frameworks. This potential will serve as a deterrent to competitiveness between NATO and the EU, for the sake of European stability.

3 Associated Press, 16 September 2003.

4 Reuters, 17 September 2003. 
Two additional points must be stressed. First, if this scenario becomes reality, the political elites identified with a Western orientation will be heavily attacked by resurgent nationalist forces. Secondly, the prospects of support of public opinion for the American deployment of military bases will become gradually less powerful due to this new balance between the nationalist and internationalist political forces.

The second scenario is based on the assumption that the present crisis in transatlantic relations will be over soon, and we will witness a return of the status quo ante, with a certain compromise made by both organizations in pursuit of the extension of international stability and security. NATO and the EU will soon reach a point where their threat assessments are identical, and their responses to the multifarious new threats will be shaped by consensus within the old framework of a renewed post-Prague NATO.

For the Balkans, this is the best and most desirable scenario. First, the processes of NATO and EU enlargement will complement each other. The only problem will be where NATO would enlarge next, in the Western Balkans or in the Caucasus, more probably in the latter area because the former could attend a new round in comfortable security being surrounded by members of both organizations.

In addition, cooperation in the region will substantially increase in all fields. The cooperative security framework developed up to this point in the classical Balkans will be extended to the Caucasus, and even to the Caspian area, enlarging the existing institutions like SEDM or creating new ones. The Greater South-Eastern Europe geographical vision will become a reality. The domestic political tensions in states in the region that are now based on competitive foreign agendas would dissipate. Russia and Ukraine would be strategic partners, or would operate more in an environment in which the military might of the U.S. will be complemented by the "soft security" skills of Europe. Coping with the threats in the Greater Middle East will be easier if this region's northern tier has a promising future of security and stability.

For the development of this scenario to proceed, the deployment of American military bases in the region will have a great positive impact, as will the decision of the European Union to undertake-alone or jointly with NATO-PSO in closer proximity to its new frontiers (as recently took place in the Transdnistrian region in the Republic of Moldova). As NATO officials declared in September 2003, "NATO nations are edging closer to an agreement that would launch military planning for an expansion of its peacekeeping operations in Afghanistan, which are currently limited to the capital, Kabul," which was a common American-German request. ${ }^{5}$

One observation regarding the feasibility of this scenario: it is not advisable to consider the return to the status quo ante without seeking a political compromise between the two sides of the Atlantic. The crisis should not be solved in a way that produces only one victor, but rather two. As Robert Hunter put it, the Allies who were against the war in Iraq, "and every other country with a stance in oil, global stability, Israel-

5 Associated Press, 17 September 2003. 
Palestine peace, ending terrorism and stopping weapons of mass destruction, have no other choice than to support the thrust of American policy." 6

The third scenario that I am proposing stems from the premises that the present transatlantic crisis will be of long duration, and that the essential task for both parties in coping with it is to avoid further damage and seek a political compromise for a new transatlantic agenda. It is not my intention to discuss where this compromise is advisable, or what should be done to reach it. I would like simply to present what developments will possibly take place in the Balkans in an environment in which the transatlantic crisis is frozen, but the two sides are making sincere efforts to solve it.

If there is a clear desire on the part of both the U.S. and Europe to overcome the crisis, one area of common understanding is a desire to continue the enlargement of NATO and EU beyond the 2004 round. This is where the interests of both parts are converging because extending security to the East is equally favorable to both. Even if the timing of the next wave of enlargement will be delayed a little, the prospects of it will have positive results in the Balkans. Non-NATO MAP countries, or prospective members, will work hard to bring this moment closer. Other countries will seek MAP status, and the same pertains to EU membership. The incentives for enhancing cooperation at the regional level will remain. Domestic political tensions will not reach the boiling point, exacerbated by the competition between the two organizations like in the first scenario. Perhaps a full-fledged extension of Balkan cooperation to the East to include the Black Sea area and the Caucasus will not materialize, but a certain interconnectivity within the region will develop. As a final point, the deployment of U.S. military bases in some countries of the Balkans will have a stabilizing effect, and will also speed up the resolution of the present transatlantic crisis.

\section{Conclusions}

What are the chances of any of these scenarios coming to fruition? Personally, I believe that the first one has no chance. Its implementation would imply a future enmity between the U.S. and Europe which is impossible today, not only because Europe is not united itself, but also because it would imply the retreat of the U.S. from the entire continent, a prospect which could not be regarded seriously in Washington. The third scenario could develop for a while in the near future until a new transatlantic agenda can be brokered. The second scenario is the most likely to develop, based on a wellbalanced compromise. It is not possible to get past the present crisis without considering the position of the opponents to the Iraq war. In the long term, a real compromise not only will save NATO but also the European Union, as well as the relevance of the West in the world. There is no alternative to the security community between the U.S. and Europe. The real challenge for the future is to identify a common agenda that will be developed jointly.

${ }^{6}$ Robert E. Hunter, in "The Perfect Army for Iraq: NATO," in the New York Times, 13 September 2003. 
THE QUARTERLY JOURNAL

A summary of the conclusions for all these scenarios could be viewed as follows:

1. The first scenario must be avoided at any price.

2. The level of cooperation between NATO and the European Union must be increased, because any fissure would raise the specter of an option to choose between the two camps, more precisely between the U.S. and the EU.

3. The likelihood of the second scenario would mean high expectations for a new wave of NATO enlargement (to include MAP countries and Ukraine). 


\section{Bibliography}

Asmus, Ronald D., and Kenneth M. Pollack. "The New Transatlantic Project - A Response to Robert Kagan." Policy Review (2002).

Hunter, Robert E.. "The Perfect Army for Iraq: NATO." New York Times (2003).

Parker, George, and Quentin Peel. "A Fractured Europe-Divisions Deepen Between Big and Small Countries, North and South, Elites and Their Electors." Financial Times (2003). 